\title{
Uma revisão crítica acerca da expropriação de direitos sociais e da saúde no capitalismo contemporâneo
}

\author{
Una revisión crítica de la expropiación de los derechos sociales y de salud en el \\ capitalismo contemporáneo

\section{A critical review of the expropriation of social and health rights in contemporary capitalism}

Recebido: 12 out 2021 Revisado: 22 nov 2021 Aceito: 22 nov 2021

Autor de correspondência: Áquilas Mendes aquilasmendes@gmail.com

Como citar: Costa APC, Mendes Á. Uma revisão crítica acerca da expropriação de direitos sociais e da saúde no capitalismo contemporâneo. J Manag Prim Health Care. 2021;13:e020.

https://doi.org/10.14295/jmphc.v13. 1176.

Conflito de interesses: Os autores declaram não haver nenhum interesse profissional ou pessoal que possa gerar conflito de interesses em relação a este manuscrito.

Copyright: Este é um artigo de acesso aberto, distribuído sob os termos da Licença Creative Commons (CC-BY-NC). Esta licença permite que outros distribuam, remixem, adaptem e criem a partir do seu trabalho, mesmo para fins comerciais, desde que the atribuam o devido crédito pela criação original.

\section{Alexsandra Pinheiro Cavalcante $\operatorname{COSTA}^{(1)}$ Áquilas $\operatorname{MENDES}^{(2,3)}$}

\author{
(1) Universidade Federal do Acre - UFAC, Cruzeiro do Sul, AC, Brasil. \\ (2) Universidade de São Paulo - USP, Faculdade de Saúde Pública - FSP, Departamento de Política, \\ Planejamento e Gestão, São Paulo, SP, Brasil. \\ (3) Pontifícia Universidade Católica de São Paulo - PUC/SP, Faculdade de Economia, Administração, \\ Contábeis e Atuariais, Departamento de Economia, São Paulo, SP, Brasil.
}

\section{Resumo}

Neste estudo, busca-se compreender de que forma a discussão da expropriação de direitos sociais, em particular, o direito à saúde no capitalismo contemporâneo, está sendo abordada pelas produções científicas marxistas. Realizou-se uma revisão sistemática crítica a partir de 17 Revistas marxistas. A estratégia de busca foi construída com os termos livres: expropriação; direitos sociais; direito à saúde; Estado Social; capitalismo contemporâneo; acumulação primitiva. Após os processos de seleção, 15 artigos foram escolhidos e discutidos com base em três dimensões de análise: expropriação e direitos sociais; expropriação e direito à saúde; e expropriação e capitalismo contemporâneo. Empreendeuse uma análise a partir do materialismo histórico-dialético e de sua fundamentação teóricometodológica, que encontra bases na razão dialética da teoria social crítica. A partir dos resultados encontrados nesta revisão, pode-se concluir que os mecanismos de expropriação utilizados pelo capital, no capitalismo contemporâneo, têm no Estado o seu garantidor, por meio do fundo público como protetor do sistema financeiro, usurpando recursos orçamentários das políticas públicas ou por via da privatização, com estímulo ao mercado livre da saúde e à entrega da gestão dos serviços públicos de saúde ao setor privado.

Descritores: Expropriação; Saúde; Direitos Sociais; Capitalismo; Revisão.

\section{Resumen}

Este estudio busca comprender cómo la discusión sobre la expropiación de los derechos sociales, en particular, el derecho a la salud en el capitalismo contemporáneo, está siendo abordada por las producciones científicas marxistas. Se realizó una revisión crítica sistemática a través de 17 Revistas Marxistas. La estrategia de búsqueda se construyó con los términos libres: expropiación; derechos sociales; derecho a la salud; Estado social; capitalismo contemporáneo; acumulación primitiva. Luego de los procesos de selección, se eligieron y discutieron 15 artículos en base a tres dimensiones de análisis: expropiación y derechos sociales; expropiación y derecho a la salud; y expropiación y capitalismo contemporáneo. Se realizó un Análisis basado en el materialismo histórico dialéctico y su fundamento teórico-metodológico, que encuentra sus bases en la razón dialéctica de la teoría social crítica. De los resultados encontrados en esta revisión se puede concluir que los mecanismos de 
expropiación que utiliza el capital, en el capitalismo contemporáneo, tienen como garante del Estado a través del fondo público como protector del sistema financiero, usurpando recursos presupuestarios de las políticas públicas o mediante la privatización, estimulando el libre mercado de la salud y la cesión de la gestión de los servicios públicos de salud al sector privado.

Palabras-claves: Expropiación; Salud; Derechos Sociales; Capitalismo; Revisión.

\begin{abstract}
This study seeks to understand how the discussion of the expropriation of social rights, in particular, the right to health in contemporary capitalism, is being addressed by Marxist scientific productions. A systematic critical review was carried out from 17 Marxist Journals. The search strategy was built with the free terms: expropriation; social rights; right to health; Social State; contemporary capitalism; primitive accumulation. After the selection processes, 15 articles were chosen and discussed based on three dimensions of analysis: expropriation and social rights; expropriation and right to health; and expropriation and contemporary capitalism. An analysis was undertaken based on dialecticalhistorical materialism and its theoretical-methodological foundation, which finds its bases in the dialectical reason of critical social theory. From the results found in this review, it can be concluded that the expropriation mechanisms used by capital, in contemporary capitalism, have the State as its guarantor, through the public fund as protector of the financial system, usurping budget resources from public policies or through privatization, stimulating the free health market and handing over the management of public health services to the private sector.

Keywords: Expropriation; Health; Social Rights; Capitalism; Review.
\end{abstract}

\title{
Introdução
}

O mundo capitalista tem levado à redução dos diretos sociais, estando a expropriação presente na gênese do capital, sendo exigida como condição de sua reprodução e expansão. $^{1}$

Boschetti ${ }^{2}$ relembra o primeiro grande processo de expropriação, chamado por Marx de 'prelúdio do revolucionamento', ocorrido no final do século XV e início do século XVI, que consistiu na dissolução dos séquitos feudais e na expulsão violenta dos camponeses de sua base fundiária.

Várias formas de violência e roubo sobre a população se seguiram no percurso histórico capitalista, como o "roubo dos bens da Igreja, a alienação fraudulenta dos domínios estatais, o furto da propriedade comunal, a transformação usurpatória, realizada com inescrupuloso terrorismo, da propriedade feudal e clânica em propriedade privada moderna $[\ldots .$.$] ", p. 804$ legislação sanguinária, entre outras, detalhadas por Marx em "A assim chamada acumulação primitiva".

Marx ${ }^{3}$ é ainda mais enfático quando se refere ao sistema colonial como a forma mais brutal da violência. Trata-se de reconhecer esse sistema como uma importante peça para assegurar a passagem do modo de produção feudal para o modo de produção capitalista, e que deixa rastros na história do capitalismo, principalmente no Brasil, por meio do peso da escravatura, ao longo de cerca de 350 anos, com a marca incontornável de uma expropriação no meio de vida e existência de grande parte dos brasileiros e brasileiras. Por essa perspectiva, as palavras de Marx são bastante significativas na análise da acumulação 
primitiva: "a violência é a parteira de toda sociedade velha que está prenhe de uma sociedade nova. Ela mesma é uma potência econômica".3, p. 821

Segundo Fontes ${ }^{4}$, para Marx, a acumulação primitiva deveria se chamar expropriação originária, por se tratar de processo histórico que resultou na retirada do elemento originário entre o trabalhador e seus meios de vida. A base do modo de produção capitalista prescinde desse processo de retirada da terra dos camponeses, promovendo a separação entre o produtor e o detentor dos meios de produção.

Neste sentido, Boschetti ${ }^{2}$ reforça a ideia: "O sentido de expropriação em Marx era retirar dos trabalhadores o único meio de subsistência de que dispunham a fim de obrigálos a vender sua força de trabalho e participar 'livremente' do processo de acumulação". 2, p. 151

No capitalismo contemporâneo, sob a predominância do capital fictício, permanecem os processos de retirada das condições de existência dos seres sociais para convertê-los em capital. Fontes ${ }^{4}$ denomina esses processos contemporâneos de expropriações secundárias que "reconduzem seres sociais à condição de trabalhadores, enquanto convertem meios de existência e de vida em capital". ${ }^{4}$ p. 33 Na realidade, se há algo que marca o contexto atual do capitalismo, no pós-1980, com intensificação das expropriações sociais, é a manifestação problemática de sua crise estrutural, no seu modo de funcionamento da tendência persistente da queda da taxa de lucro e da dominância do capital portador de juros, na sua forma mais perversa de capital fictício, no movimento do capital. ${ }^{5}$ Essa nova etapa do capitalismo contemporâneo tem o neoliberalismo como a nova razão do mundo, reduzindo os direitos trabalhistas e sociais no âmbito da sociabilidade capitalista. ${ }^{6}$

Para a compreensão da categoria referente à expropriação, foco do interesse deste estudo, concorda-se com Fontes ${ }^{4}$ quando a autora diz que a historicidade presente no capitalismo permite entender que:

[...] qualquer atividade que permita a conexão mais ou menos direta entre ser social e meios de vida pode sofrer tal expropriação, uma vez que o processo é simultaneamente a transformação de tais meios de vida em capital e a imposição de uma única forma de propriedade, a do capital. ${ }^{4, ~ p . ~} 31$

Nesse contexto, Boschetti ${ }^{7}$ discute, no capitalismo contemporâneo, que os processos de supressão das condições de subsistência garantidas pelos direitos conquistados, como, por exemplo, aposentadorias e seguro saúde, retirando as condições materiais que possibilitam a cessação da venda da força de trabalho pela classe trabalhadora, caracterizam-se como expropriação secundária.

O capitalismo possui crises inerentes ao seu processo que denotam contradições na sua produção e reprodução, ${ }^{7}$ e, para sua expansão, a busca pela valorização do valor tem 
ISSN 2179-6750

procurado novas fontes para seu alcance. Desta maneira, a supressão de direitos tem sido um dos mecanismos utilizados na expansão capitalista, sendo o Estado seu provedor. ${ }^{8}$

No século XX, no contexto das políticas sociais e dos direitos por elas materializados com a institucionalização do Estado Social, após a crise de 1929, e sua expansão, especialmente a partir da II Guerra Mundial, há de se analisar na essência a noção de que todos os cidadãos são sujeitos de direitos, pois é na essência que se verifica a verdadeira dinâmica e determinação do Estado Social, em que há o direito sustentando a lógica da reprodução do capital. "O Estado é a própria expressão das relações capitalistas" 2, p. 135

Nessa mesma linha de raciocínio, Mascaro ${ }^{9}$ comenta que o Estado representa um aparelho necessário à reprodução do capital, garantindo a troca das mercadorias, assegurando sua forma-valor e a exploração da força de trabalho na sua forma assalariada. Trata-se de entender que o Estado não é burguês por intenção de seus governantes, mas, sim, pela sua forma social. Seu estabelecimento ocorre quando a exploração e a expropriação se assentam no interior da sociabilidade capitalista. ${ }^{9}$

Quando se analisa a expropriação dos direitos sociais no Brasil, merece que se pondere a especificidade de seu caso. Isso porque os direitos sociais e o direito à saúde por meio do Sistema Único de Saúde - SUS foram especialmente introduzidos por meio da Constituição Federal de 1988, num contexto de democracia, considerada por Demier, ${ }^{10}$ blindada para os setores populares. Inclusive, no interior da Constituição, foi instituída a Seguridade Social, de caráter restrito, quando comparado aos países capitalistas centrais, incluindo apenas as áreas de previdência, saúde e assistência social ${ }^{11}$. Dessa forma, cabe a ponderação de que, ao se expropriar direitos em algo que não é pleno, torna-se ainda mais particular o caráter da expropriação secundária a que se referem Fontes ${ }^{4}$ e Boschetti ${ }^{2}$.

Entretanto, deve-se admitir que a universalidade, ainda que institucional, trouxe algum alento para a classe trabalhadora, particularmente quando se verificam os locais extremos do Brasil, por exemplo, os estados da Amazônia em que o SUS é hegemônico na oferta direta da atenção à saúde em suas dimensões assistenciais e de vigilância em saúde.

Por sua vez, reconhece-se que no capitalismo contemporâneo vêm sendo intensificados os ataques à saúde pública universal no Brasil, ampliando a fragilidade do SUS. Observam-se, nos 33 anos de existência desse sistema, permanentes conflitos e medidas claras de diminuição de sustentabilidade de recursos financeiros e introdução de modalidades privatizantes de gestão. ${ }^{12}$

Nessa perspectiva, seguindo Fontes $^{4}$ e Boschetti, ${ }^{2}$ pode-se afirmar que essas expropriações contemporâneas arrancam dos seres sociais suas condições de existência da vida social, como no caso da saúde universal, sendo cada vez mais apropriado pelo capital de acordo com sua lógica de valorização. Assiste-se, de forma crescente, à transformação 
ISSN 2179-6750

da saúde como direito para a saúde enquanto consumo privado, com destaque para o mais recente lócus de apropriação do capital privado, a atenção primária à saúde do SUS. ${ }^{5}$

Os campos do trabalho e dos direitos sociais sofrem perdas em decorrência da crise do capital, por meio, por exemplo, das pressões dos compromissos firmados pelos vários governos federais após os anos 1990 para o pagamento de juros e amortização de dívidas, gerando redução de investimentos em direitos e serviços públicos, além de aumento de impostos sobre a classe trabalhadora, caracterizando um processo de expropriação. ${ }^{7}$

Compreender esse processo de expropriação dos direitos sociais e da saúde na contemporaneidade requer a apreensão das discussões que estão sendo realizadas, assim, interessa aqui conhecer como a literatura marxista vem discutindo essa temática. Portanto, o objetivo deste artigo é analisar, nessa literatura, o tema da expropriação de direitos sociais no capitalismo contemporâneo e sua relação com a saúde.

\section{Metodologia}

Trata-se de um estudo de revisão crítica da literatura marxista brasileira para responder à seguinte pergunta de pesquisa: O que a literatura marxista brasileira tem disponibilizado sobre o tema da expropriação de direitos sociais no capitalismo contemporâneo e sua relação com a saúde?. Busca-se compreender de que forma a discussão da expropriação de direitos sociais, em particular, o direito à saúde, no capitalismo contemporâneo está sendo abordada pelas produções científicas marxistas.

Iniciou-se a revisão crítica pela escolha das revistas marxistas que se aproximam da temática do estudo. Dessa forma, optou-se pelas revistas nacionais, uma vez que o escopo do estudo se refere ao contexto brasileiro. Portanto, foram escolhidas 17 revistas acadêmicas: "Crítica Marxista"; "Cadernos Cemarx"; "Marx e o Marxismo"; "Katálysis"; "Serviço Social e Sociedade"; "Ser Social"; "Em Pauta"; "Sociedade em Debate"; "Tempo Social"; "Lutas Sociais"; "Serviço Social e Saúde"; "Verinotio"; "Outubro"; "Trabalho, Educação e Saúde"; "Temporalis"; "Argumentum"; "Políticas Públicas". Algumas dessas revistas não são exclusivamente marxistas, mas contêm, em grande número, artigos que se originam do pensamento marxiano.

A coleta de dados ocorreu em etapas, que consistiram em mapeamento inicial, identificação das publicações, rastreamento, elegibilidade, inclusão dos artigos, conforme indicado na Figura 1 - Fluxograma de seleção de estudos. É importante mencionar que a busca das publicações não se restringiu a um período específico ao longo dos anos, permitindo que fosse contemplado um vasto intervalo de tempo. Certamente, a pergunta de pesquisa centraliza o momento do capitalismo contemporâneo, o que abrange um 
ISSN 2179-6750

período após os anos 1990. Dessa forma, os artigos incluídos na presente revisão abrangem o período de 1998 a 2020. Além disso, é importante mencionar que a busca dos artigos para a revisão foi elaborada nos meses de junho e julho de 2020.

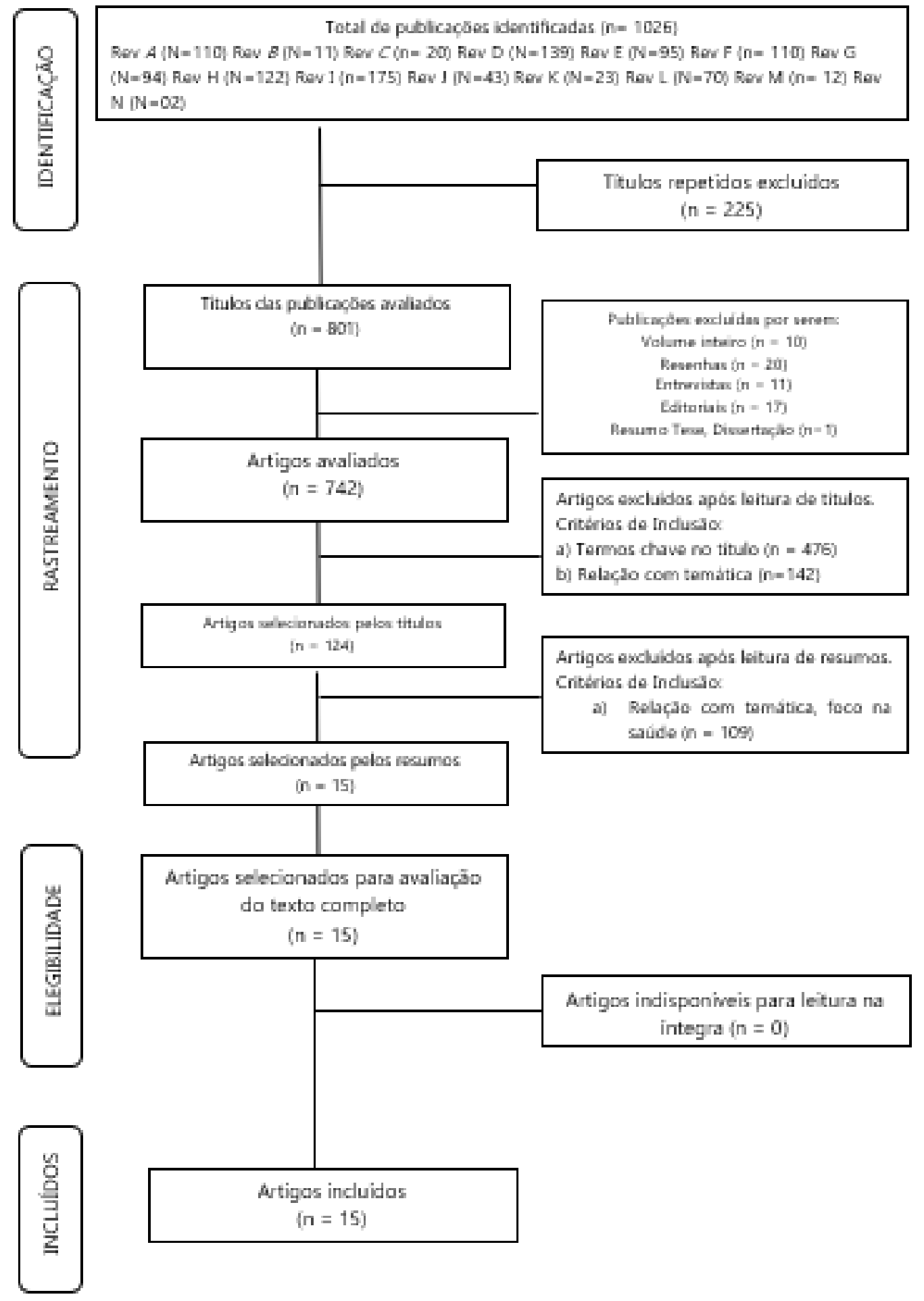

Figura 1. Fluxograma do processo de seleção dos artigos incluídos na revisão sobre expropriação de direitos sociais no capitalismo contemporâneo e sua relação com a saúde Fonte: Elaborado pelos autores (2021). 
Na etapa de mapeamento das publicações, foi realizada a pesquisa por assunto nas páginas virtuais das revistas, utilizando separadamente os termos livres primários: "expropriação"; "direitos sociais"; "direito à saúde"; "Estado Social"; "capitalismo contemporâneo"; "acumulação primitiva". Esses termos foram pensados a partir de sua relação com a pergunta de pesquisa.

A revista "Argumentum" apresentou problemas em sua página de busca e não retornou resultados, sendo excluída do estudo nesse passo.

Após o mapeamento inicial, foi realizada uma primeira combinação nas revistas por meio de termos livres primários: "direitos sociais"; "direito à saúde"; "capitalismo contemporâneo", acrescidos do operador booleano " $A N D^{\prime}$ e da combinação dos seguintes termos secundários (Desmonte OR Ataques OR Regressões OR Negação OR Desafios OR Neoliberal). O termo livre primário "Estado Social "foi combinado com o operador booleano " $A N D^{\prime}$ e a combinação dos seguintes termos secundários (Desmonte OR Ataques OR Regressões OR Negação OR Desafios OR Neoliberal OR Capital). A escolha desses termos para as combinações se deu pelo critério de relação com a temática da expropriação dos direitos sociais e após uma leitura rápida dos títulos dos artigos encontrados nos resultados iniciais.

Em seguida, houve a necessidade de combinar o termo livre "Estado Social" separadamente com cada termo secundário, especialmente na revista "Sociedade em Debate", que não retornou resultados. Então, seguiu-se a combinação (Estado Social AND Desmonte; Estado Social AND Ataques; Estado Social AND Regressões; Estado Social AND Negação; Estado Social AND Desafios; Estado Social AND Neoliberal; Estado Social AND Capital). Após essa combinação, reduziu-se o número de publicações encontradas.

A revista "Tempo Social" consiste em um periódico heterodoxo, único e diferente dos demais marxistas. Por ser de grande importância para as Ciências Sociais e Humanas, a revista foi incluída neste estudo, sendo utilizado o operador booleano ANDe o termo "Marx" em suas buscas para tentar captar apenas artigos marxistas. Já a Revista Políticas Públicas apresentou problemas em sua página de busca e não permitia a visualização de todos os resultados quando o número era superior a 20. Dessa forma, o periódico foi excluído do estudo nessa fase.

Após esse mapeamento geral, a busca obteve $\mathbf{1 . 0 2 6}$ publicações totais na fase de identificação, conforme apresenta o Fluxograma (Figura 1). Em seguida, foram retirados 225 resultados repetidos, permanecendo 801 no total.

$\mathrm{Na}$ fase seguinte, de rastreamento, foram excluídas 59 publicações referentes a volumes inteiros, resenhas, entrevistas, editoriais, resumos de teses e dissertações. Permaneceram 742 artigos que tiveram seus títulos lidos em dois passos (Figura 1). 
Na primeira leitura dos títulos, utilizou-se a presença de termos-chave, como critério de inclusão. Tais termos foram: Estado, sociedade civil; políticas públicas, políticas sociais; acumulação; agrário; neoliberalismo; financeirização; cidadania; capitalismo; expropriação; dominação. A escolha desses termos se deu pela materialidade trazida pela leitura realizada anteriormente. Após essa seleção, foram excluídos 476 artigos, permanecendo 266.

Procedeu-se a uma segunda leitura dos títulos, a fim de executar um segundo filtro que se relacionasse com a temática, utilizando os mesmos termos-chave da primeira leitura. Desse modo, havia ainda 142 artigos, permanecendo 124 no total (Figura 1).

A próxima fase consistiu na leitura dos resumos dos artigos científicos, que utilizou como critério de inclusão a abordagem à expropriação secundária; à expropriação de direitos sociais com foco na saúde; ao capitalismo nos anos 1970 e 1980. Finalizada essa etapa de leitura dos resumos, foram retirados 109 artigos, restando 15, que foram selecionados para a leitura na íntegra, e, finalmente, todos considerados como artigos incluídos (Figura 1).

A Figura 1 permite visualizar as etapas de busca a partir da identificação das publicações.

A análise dos 15 artigos incluídos se apoiou no materialismo histórico-dialético. Sua fundamentação teórico-metodológica encontra bases na razão dialética da teoria social crítica, pois essa permite entender a totalidade a partir da análise do sentido da expropriação dos direitos sociais, em geral, e da saúde, em particular, utilizada nesta pesquisa.

Netto $^{13}$, ao se referir ao método de Marx, explicita que:

[...] o conhecimento teórico é o conhecimento do objeto - de sua estrutura e dinâmica - tal como ele é em si mesmo, na sua existência real e efetiva, independentemente dos desejos, das aspirações e das representações do pesquisador. A teoria é para Marx, a reprodução ideal do movimento real do objeto pelo sujeito que pesquisa: pela teoria, o sujeito reproduz em seu pensamento a estrutura e a dinâmica do objeto que pesquisa. E esta reprodução será tanto mais correta e verdadeira quanto mais fiel o sujeito for ao objeto. 13, p.20-21

O método marxiano permite ter uma apreensão da sociedade, entender a partir da totalidade, da mediação e da contradição o que está posto no real concreto. Esse método pode ser caracterizado, depois da etapa de investigação, como de exposição, explicitando a contradição e a crítica. Dessa forma, destaca-se o modo como o objeto, suficientemente apreendido e analisado, desdobra-se em suas articulações próprias e como o pensamento as desenvolve em suas determinações conceituais correspondentes, organizando um discurso metódico. ${ }^{14}$ 
A revisão crítica dos artigos marxistas selecionados constitui um desafio, na medida em que se assegura a perspectiva analítica no âmbito da visão marxista, sem que se abordem, de forma pormenorizada, os limites das suas diversas correntes. ${ }^{15}$

\section{Resultados e discussão}

Para uma visão geral dos argumentos dos 15 artigos incluídos, é apresentada no Quadro $1^{12,16-29}$ uma síntese que destaca autores, método dos estudos, abordagens sobre expropriação e direitos sociais, expropriação e direito à saúde, expropriação e capitalismo contemporâneo.

\begin{tabular}{|c|c|c|c|}
\hline Autores/Ano & Método & $\begin{array}{l}\text { Expropriação e } \\
\text { direitos sociais }\end{array}$ & $\begin{array}{l}\text { Expropriação e } \\
\text { direito à saúde }\end{array}$ \\
\hline $\begin{array}{l}\text { Bravo MIS, } \\
\text { Pelaez EJ, } \\
\text { Menezes } \\
\text { JSB, } 2020^{16}\end{array}$ & $\begin{array}{l}\text { Análise } \\
\text { documental } \\
\text { (abordagem } \\
\text { qualitativa) }\end{array}$ & Não apresenta & $\begin{array}{l}\text { A proposição do (Sistema Único de Saúde) } \\
\text { SUS possível; fortalecimento do projeto } \\
\text { privatista, com maior participação da iniciativa } \\
\text { privada na gestão dos serviços de saúde; } \\
\text { proposição de planos de saúde acessíveis } \\
\text { Cortes orçamentários na política de saúde } \\
\text { com desonerações, abdicação do } \\
\text { recolhimento da Cofins e congelamento de } \\
\text { recursos por } 20 \text { anos }\end{array}$ \\
\hline $\begin{array}{l}\text { Costa LTC, } \\
\text { Soares RC, } \\
2020^{17}\end{array}$ & $\begin{array}{l}\text { Levantamento } \\
\text { bibliográfico e } \\
\text { análise } \\
\text { qualitativa } \\
\text { (dados } \\
\text { secundários) }\end{array}$ & Não apresenta & $\begin{array}{l}\text { Estímulo do mercado privado da saúde: } \\
\text { parceria público-privada na gestão dos } \\
\text { serviços; isenções fiscais } \\
\text { Congelamento dos gastos públicos por } 20 \\
\text { anos (Emenda Constitucional -EC 95/2016) } \\
\text { Desvinculação da despesa federal com saúde } \\
\text { Participação de grupos corporativos na } \\
\text { definição de políticas e formulação da } \\
\text { legislação setorial } \\
\text { Fortalecimento de uma retórica antiSUS } \\
\text { Refuncionalização do direito à saúde segundo } \\
\text { a lógica do mercado } \\
\text { Orientação estatal para acesso vinculada à } \\
\text { inserção no trabalho formal }\end{array}$ \\
\hline $\begin{array}{l}\text { Mendes A, } \\
\text { Carnut L, } \\
2020^{12}\end{array}$ & $\begin{array}{l}\text { Ensaio Crítico } \\
\text { (abordagem } \\
\text { qualitativa) }\end{array}$ & Não apresenta & $\begin{array}{l}\text { Mecanismos de subfinanciamento do SUS: } \\
\text { apropriação do fundo público na saúde pelo } \\
\text { capital fictício; Desvinculação das Receitas da } \\
\text { União - DRU; renúncias fiscais; aprovação da } \\
\text { EC 86/2015; expropriação dos recursos do } \\
\text { Orçamento da Seguridade Social } \\
\text { Privilegiamento da operação do direito privado à } \\
\text { saúde } \\
\text { Nos últimos } 30 \text { anos, o Estado brasileiro dá } \\
\text { incentivos à iniciativa privada } \\
\text { Desfinanciamento do SUS: Aprovação EC } \\
\text { 95/2016 }\end{array}$ \\
\hline
\end{tabular}


ISSN 2179-6750

\begin{tabular}{|c|c|c|c|}
\hline Autores/Ano & Método & $\begin{array}{l}\text { Expropriação e } \\
\text { direitos sociais }\end{array}$ & $\begin{array}{l}\text { Expropriação e } \\
\text { direito à saúde }\end{array}$ \\
\hline $\begin{array}{l}\text { Cislaghi JF, } \\
2019^{18}\end{array}$ & $\begin{array}{l}\text { Ensaio Crítico } \\
\text { (abordagem } \\
\text { qualitativa) }\end{array}$ & Não apresenta & $\begin{array}{l}\text { Criação do Programa Farmácia Popular com } \\
\text { um copagamento entre o Estado e os usuários } \\
\text { Repasse de recursos do fundo público ao } \\
\text { setor privado: pagamento de planos de saúde } \\
\text { privados para o funcionalismo público; } \\
\text { renúncia fiscal da União } \\
\text { Captura da Agência Nacional de } \\
\text { Saúde - ANS } \\
\text { Mecanismo chamado "dupla porta"; os planos } \\
\text { de saúde não arcam com procedimentos } \\
\text { caros e complexos } \\
\text { Precarização dos contratos de trabalho da } \\
\text { saúde }\end{array}$ \\
\hline $\begin{array}{l}\text { Alencar } \\
\text { Júnior OG, } \\
\text { Salvador ES, } \\
2015^{19}\end{array}$ & $\begin{array}{l}\text { Análise } \\
\text { qualitativa dos } \\
\text { dados } \\
\text { secundários }\end{array}$ & $\begin{array}{l}\text { Participação reduzida de } \\
\text { recursos de outras fontes } \\
\text { no financiamento da } \\
\text { Seguridade Social } \\
\text { Crescimento das } \\
\text { contribuições dos } \\
\text { trabalhadores; } \\
\text { desonerações da folha de } \\
\text { pagamento }\end{array}$ & $\begin{array}{l}\text { Mecanismos de subfinanciamento do SUS: a } \\
\text { CSLL não teve sua posição alterada em termos } \\
\text { de participação; extinção da CPMF }\end{array}$ \\
\hline $\begin{array}{l}\text { Lourenço } \\
\text { EAS, } 2015^{20}\end{array}$ & $\begin{array}{l}\text { Análise } \\
\text { qualitativa de } \\
\text { documentos, } \\
\text { entrevista }\end{array}$ & $\begin{array}{l}\text { Em 2015, aprovado PL de } \\
\text { ampla terceirização do } \\
\text { trabalho } \\
\text { Anos 1990, os direitos do } \\
\text { trabalho foram taxados de } \\
\text { riscos empresariais } \\
\text { As políticas sociais elevadas } \\
\text { à categoria de privilégios e } \\
\text { de impedimentos para o } \\
\text { desenvolvimento } \\
\text { econômico }\end{array}$ & $\begin{array}{l}\text { As políticas de saúde e segurança no trabalho, } \\
\text { desenvolvidas por algumas empresas, } \\
\text { geralmente são repressivas } \\
\text { Os trabalhadores sofrem pressões para não } \\
\text { notificarem acidentes de trabalho ou agravos } \\
\text { à saúde }\end{array}$ \\
\hline $\begin{array}{l}\text { Ferreira } \\
\text { AMA, } \\
\text { Amaral AS, } \\
2014^{21}\end{array}$ & $\begin{array}{l}\text { Abordagem } \\
\text { qualitativa }\end{array}$ & $\begin{array}{l}\text { Orientações de } \\
\text { organizações } \\
\text { internacionais: tendência } \\
\text { da mercantilização dos } \\
\text { direitos sociais e } \\
\text { focalização das ações } \\
\text { desregulamentação dos } \\
\text { direitos sociais } \\
\text { Trabalhador com doença } \\
\text { relacionada ao trabalho } \\
\text { com dificuldade em manter } \\
\text { benefícios previdenciários }\end{array}$ & $\begin{array}{l}\text { Desmonte do sistema de saúde } \\
\text { Trabalhador com doença relacionada ao } \\
\text { trabalho com dificuldades de acesso aos } \\
\text { serviços de saúde }\end{array}$ \\
\hline
\end{tabular}


ISSN 2179-6750

\begin{tabular}{|c|c|c|c|}
\hline Autores/Ano & Método & $\begin{array}{l}\text { Expropriação e } \\
\text { direitos sociais }\end{array}$ & $\begin{array}{l}\text { Expropriação e } \\
\text { direito à saúde }\end{array}$ \\
\hline $\begin{array}{l}\text { Sousa AMC, } \\
2014^{22}\end{array}$ & $\begin{array}{l}\text { Pesquisa } \\
\text { teórica } \\
\text { (bibliográfica e } \\
\text { documental) } \\
\text { (abordagem } \\
\text { qualitativa) }\end{array}$ & Não apresenta & $\begin{array}{l}\text { Focalização: desde os anos 1990, as } \\
\text { organizações financeiras internacionais } \\
\text { colocam o acesso à saúde pelo mercado, e o } \\
\text { Estado garante apenas aos pobres } \\
\text { Privatização interditou o projeto da reforma } \\
\text { sanitária } \\
\text { No governo petista, houve maior abertura à } \\
\text { expansão do setor privado: oferta/venda de } \\
\text { serviços ao SUS, manutenção de mecanismos } \\
\text { de renúncia fiscal; e inserção das novas } \\
\text { modalidades de gestão (terceirizações, } \\
\text { fundações e Organizações Sociais) }\end{array}$ \\
\hline $\begin{array}{l}\text { Santos MA, } \\
2013^{23}\end{array}$ & $\begin{array}{l}\text { Pesquisa } \\
\text { bibliográfica e } \\
\text { análise } \\
\text { documental } \\
\text { (abordagem } \\
\text { qualitativa) }\end{array}$ & $\begin{array}{l}\text { Concretização de uma } \\
\text { cultura privatista da } \\
\text { Seguridade Social -SS a } \\
\text { partir de } 1990\end{array}$ & $\begin{array}{l}\text { Política de Saúde caracterizada por } \\
\text { privatização, focalização e precarização } \\
\text { Privatização via Fundações Estatais de Direito } \\
\text { Privado, novos modelos de gestão, } \\
\text { neutralização do controle social }\end{array}$ \\
\hline $\begin{array}{l}\text { Davi J, Serpa } \\
\text { MA, Silva } \\
\text { SSS, } \\
\text { Medeiros } \\
\text { Júnior G, } \\
\text { Santos } \\
\text { MAN, } \\
2010^{24}\end{array}$ & $\begin{array}{l}\text { Análise } \\
\text { qualitativa de } \\
\text { dados } \\
\text { financeiros }\end{array}$ & $\begin{array}{l}\text { Mercantilização, focalização } \\
\text { e descentralização das } \\
\text { políticas sociais, } \\
\text { privatização dos serviços } \\
\text { públicos } \\
\text { Desfinanciamento dos } \\
\text { direitos sociais; } \\
\text { desvinculações dos } \\
\text { recursos financeiros: em } \\
2000 ; \text { apologia do ajuste } \\
\text { fiscal } \\
\text { Processo de "liberalização" } \\
\text { da seguridade social }\end{array}$ & $\begin{array}{l}2000 \text { - 2007: três vezes mais gastos com } \\
\text { pagamento da dívida do que com o setor } \\
\text { saúde } \\
\text { Mercantilização da saúde }\end{array}$ \\
\hline $\begin{array}{l}\text { Nogueira } \\
\text { VMR, } 2009^{25}\end{array}$ & $\begin{array}{l}\text { Ensaio Crítico } \\
\text { (abordagem } \\
\text { qualitativa) }\end{array}$ & Não apresenta & $\begin{array}{l}\text { Mercantilização da saúde: a partir dos anos } \\
1970 \text { identificação das ações e dos serviços de } \\
\text { saúde como atividades lucrativas }\end{array}$ \\
\hline $\begin{array}{l}\text { Calipo SM, } \\
\text { Soares CB, } \\
2008^{26}\end{array}$ & $\begin{array}{l}\text { Análise } \\
\text { documental } \\
\text { (abordagem } \\
\text { qualitativa) }\end{array}$ & Não apresenta & $\begin{array}{l}\text { Anos } 1990 \text { - criação de Organizações Sociais } \\
\text { A privatização da saúde: flexibilização das } \\
\text { relações de trabalho e desregulamentação; o } \\
\text { direito privado regendo as relações com o } \\
\text { Estado } \\
\text { Perda do direito à saúde pela restrição da } \\
\text { assistência às carências de grupos } \\
\text { considerados de risco }\end{array}$ \\
\hline
\end{tabular}


ISSN 2179-6750

\begin{tabular}{|c|c|c|c|}
\hline Autores/Ano & Método & $\begin{array}{l}\text { Expropriação e } \\
\text { direitos sociais }\end{array}$ & $\begin{array}{l}\text { Expropriação e } \\
\text { direito à saúde }\end{array}$ \\
\hline $\begin{array}{l}\text { Dal Prá KR, } \\
2008^{27}\end{array}$ & $\begin{array}{l}\text { Pesquisa } \\
\text { documental } \\
\text { (abordagem } \\
\text { qualitativa) }\end{array}$ & $\begin{array}{l}\text { Apropriação dos direitos e } \\
\text { políticas sociais como } \\
\text { possibilidades de lucro } \\
\text { Redução do Estado por } \\
\text { meio de privatização, } \\
\text { terceirização e publicização }\end{array}$ & $\begin{array}{l}\text { A atenção à saúde remetida ao interior do } \\
\text { mercado } \\
\text { Transferência da gestão dos serviços de saúde } \\
\text { para OS } \\
\text { Orientações Banco Mundial: pacote básico de } \\
\text { serviços clínicos e de prioridades de } \\
\text { financiamento; copagamento }\end{array}$ \\
\hline $\begin{array}{l}\text { Marques } \\
\text { RM, Mendes } \\
\text { A, } 2007^{28}\end{array}$ & $\begin{array}{l}\text { Ensaio Crítico } \\
\text { (abordagem } \\
\text { qualitativa) }\end{array}$ & $\begin{array}{l}\text { Em 2003, aprovação do } \\
\text { projeto de contrarreforma } \\
\text { da previdência social dos } \\
\text { funcionários públicos } \\
\text { Permanência do domínio } \\
\text { do trabalho informal no } \\
\text { mercado }\end{array}$ & $\begin{array}{l}\text { Em 2003, defesa de desvinculação de receitas } \\
\text { para o SUS } \\
\text { Em 2004, redução do orçamento ao MS } \\
\text { Descumprimento da Emenda Constitucional } \\
29 \text { pela União } \\
\text { Em } 2004 \text { e } 2005 \text {, tentativa de inclusão, nos } \\
\text { gastos orçamentários, de atividades que não } \\
\text { são consideradas típicas da saúde pública }\end{array}$ \\
\hline $\begin{array}{l}\text { Simionatto I, } \\
\text { Nogueira } \\
\text { VMR, } 1998^{29}\end{array}$ & $\begin{array}{l}\text { Ensaio Crítico } \\
\text { (abordagem } \\
\text { qualitativa) }\end{array}$ & $\begin{array}{l}\text { Utilização dos fundos } \\
\text { públicos para reprodução } \\
\text { do capital } \\
\text { "definição" do que é ou } \\
\text { não é direito imposta aos } \\
\text { Estados nacionais pelas } \\
\text { agências e grupos } \\
\text { econômicos transnacionais } \\
\text { Delimitação das funções do } \\
\text { Estado por meio de } \\
\text { privatização e terceirização }\end{array}$ & Não apresenta \\
\hline
\end{tabular}

Quadro 1. Artigos incluídos na revisão segundo autores, método dos estudos, expropriação e direitos sociais, expropriação e direito à saúde, expropriação e capitalismo contemporâneo Fonte: Elaborado pelos autores (2021).

\section{Expropriação e direitos sociais}

Nesta dimensão, a primeira temática, o processo de privatização, foi recorrente em cinco artigos. ${ }^{21,23,24,27,29}$

Ferreira e Amaral ${ }^{21}$ argumentam sobre a influência de diretrizes de organizações internacionais multilaterais com tendência para a mercantilização dos direitos sociais direcionando-os a uma parcela específica da sociedade.

Santos $^{23}$ aborda o tema constatando que há uma concretização de uma cultura privatista da Seguridade Social brasileira a partir dos anos 1990, com a assistência social como política social específica para os pobres e a previdência social direcionada ao cidadão consumidor, via processo de mercantilização.

Davi et al. ${ }^{24}$ trazem o tema da privatização enfocando a mercantilização das políticas sociais, a liberalização da seguridade social, que tem a reconstituição do mercado entre seus eixos principais para desenvolvimento das políticas sociais, e, ainda, a privatização dos 
ISSN 2179-6750

serviços públicos. "Estas estratégias passam pela privatização das empresas estatais e pela apropriação de espaços até então ocupados pela política social, convertidos em mercadoria e transmutados em negócios operados pela iniciativa privada". 24, p. 78

Dal Prá ${ }^{27}$ assinala a apropriação dos direitos sociais e das políticas sociais como possibilidade de lucro e a redução do Estado por meio de privatização e da terceirização no contexto de reforma do Estado brasileiro, em que este não deve executar várias funções diretamente, deixando para o setor privado e para o público não estatal.

Simionatto e Nogueira, ${ }^{29}$ discutindo a questão do ajuste econômico e dos direitos sociais, também abordam a temática do processo de privatização jogando luz sobre a delimitação das funções do Estado com a transferência de funções do setor público para o setor privado por meio da privatização e da terceirização.

O processo de expropriação dos direitos sociais tem sido acirrado pelo avanço da privatização, soberania do mercado e terceirização, que consistem em características do neoliberalismo e que têm o Estado como articulador dos interesses privados, sendo mínimo para o social e máximo para o capital. ${ }^{30}$

Ferreira e Mendes ${ }^{31}$ abordam a temática da privatização por meio da particularidade do termo mercantilização e a diferenciam em processo explícito e implícito. Com relação ao processo explícito, os autores compreendem que ele se configura "quando envolve direta transferência de responsabilidade do setor público para o privado", 23, p. 2161 enquanto o processo implícito "caracteriza-se pela adoção crescente de uma lógica de atuação privada por parte do setor público". 31, p. 2161 Entre os artigos analisados, observou-se a expressão de ambos os processos: no explícito, com o direcionamento da previdência social ao cidadão consumidor; no implícito, com o setor privado e público não estatal gerindo setores públicos.

A segunda temática, o financiamento, foi enfocada nessa dimensão em quatro $\operatorname{artigos}^{19,24,28,29}$

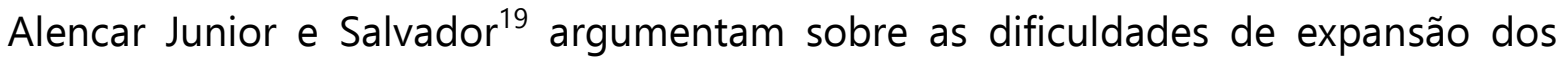
recursos orçamentários para a efetivação dos direitos sociais em virtude da difusão da ideologia neoliberal, com crescimento explosivo de recursos de outras fontes, mas pouca participação no financiamento da seguridade social. Os autores demonstram o crescimento da fonte de contribuições da classe trabalhadora no governo Fernando Henrique Cardoso (FHC), com manutenção no governo Lula, e, ainda, as desonerações da folha de pagamento que afetam diretamente o Orçamento da Seguridade Social - OSS, pois metade de seus recursos vem da Contribuição de Empregados e Empregadores.

Davi et $a^{24}{ }^{24}$ discutem a tendência de desfinanciamento dos direitos sociais em benefício do pagamento dos juros da dívida pública, tendo a diminuição dos gastos públicos 
ISSN 2179-6750

como uma de suas fontes de obtenção de recursos. Entre os mecanismos para a efetivação desse desfinanciamento está a criação da Desvinculação das Receitas da União - DRU em uma conjuntura de ajuste fiscal implementado pelos governos brasileiros no contexto dos anos pós-1990. Inicialmente, a DRU passou a desvincular $20 \%$ das receitas de impostos e contribuições da União para outros fins que não aqueles destinados constitucionalmente, expropriando as fontes de custeio da seguridade. Contudo, cabe mencionar que, a partir da Emenda Constitucional n. 93/2015, houve alteração na alíquota desse mecanismo, passando para 30\%, em vigor até $2023 .^{12}$

Marques e Mendes ${ }^{28}$ expõem o alinhamento do governo Lula com a redução de direitos em nome do superávit fiscal, e, na dimensão dos direitos sociais, encontra-se a proposição do projeto da contrarreforma da previdência social dos funcionários públicos, sob a justificativa de existir um déficit previdenciário no programa de governo. Tal contrarreforma foi aprovada no final do primeiro ano de mandato, em 2003.

Simionatto e Nogueira ${ }^{29}$ apontam para a diminuição dos recursos de manutenção dos direitos sociais pela apropriação do fundo público em prol da reprodução do capital, contribuindo para redução das ações estatais e dificultando a inclusão da garantia dos direitos na agenda estatal.

Nessa linha de raciocínio, Behring ${ }^{32}$ ilumina assinalando que, no capitalismo contemporâneo, com o predomínio do neoliberalismo e da financeirização, o fundo público assume cada vez mais proporções e funções, com o Estado extraindo e transferindo parcela significativa da mais-valia socialmente produzida para a socialização dos custos da crise, em uma dinâmica de valorização do capital.

Nesse cenário do capitalismo sob a dominância financeira, intensificam-se os interesses do capital portador de juros pelo fundo público brasileiro, utilizando-se de mecanismos específicos para usurpar o orçamento federal por meio das despesas com juros da dívida pública. ${ }^{33}$

Ainda para Behring, ${ }^{34}$ o fundo público, em caso de crise do capital, é utilizado como gestor de riscos no sistema nacional de crédito, injetando dinheiro e, assim, constituindo-se como um garantidor do sistema.

Quanto à terceira temática, os efeitos para a classe trabalhadora, três artigos $20,21,28$ fazem essa abordagem no contexto da dimensão dos direitos sociais.

Lourenço ${ }^{20}$ explana acerca da perda de direitos trabalhistas e previdenciários, sendo que, por intermédio da terceirização, "o capitalismo se livra dos 'excessos' dos gastos direcionados à força de trabalho", 20, p. 451 em um contexto de crise do capital em que "os direitos do trabalho foram taxados de riscos empresariais" e "as políticas sociais foram elevadas à categoria de privilégios e de impedimentos para o desenvolvimento econômico, 
ISSN 2179-6750

diga-se de maior acumulação capitalista". 20, p. 451 A autora aponta que em todos os governos brasileiros, desde Collor, desenvolveu-se uma ampla rede de informalidade no Brasil, que se traduz em más condições de trabalho, baixos salários e aumento da jornada.

Ferreira e Amaral ${ }^{21}$ destacam, também, os prejuízos advindos de relações de trabalho precarizadas e do mercado informal, uma vez que os trabalhadores têm dificuldades para acessar os benefícios previdenciários ou para mantê-los, quando, por exemplo, da continuidade de incapacidade decorrente do trabalho.

Marques e Mendes ${ }^{28}$ fazem menção ao recuo do rendimento médio dos ocupados e ao resultado de geração de emprego formal no governo Lula, que ficou longe do prometido em campanha eleitoral e "estaria fundado na permanência do domínio do trabalho informal no mercado". 28, p.22

Os efeitos para a classe trabalhadora apontados pelos artigos analisados confirmam uma das causas contra-arrestantes da tendência da queda da taxa de lucro descrita por Marx, ${ }^{35}$ que se refere à ampliação do grau de exploração do trabalho por meio do aumento da jornada de trabalho e da intensificação do trabalho.

Essa exploração do trabalho se concretiza por meio da ação do Estado, conforme apontam Mendes, Alcantara e Alcantara Filho. 30, p, 72. "torna-se evidente o caráter do Estado em salvaguardar a forma do capital, colocando-se na dianteira da intensificação da exploração da força de trabalho, na garantia de instrumentos que precarizam as condições de contratação e perda de direitos sociais".

\section{Expropriação e direito à saúde}

Nesta dimensão, a primeira temática, o processo de privatização, está contemplada em nove artigos. ${ }^{12,16,17,22,23,24,25,26,27}$

Bravo, Pelaez e Menezes ${ }^{16}$ discutem os projetos de saúde em disputa, entre os quais, está o projeto privatista que "tem sua lógica orientada pelas regras de mercado e pela exploração da doença como fonte de lucros". ${ }^{16, \text { p. } 194}$ e, já na década de 1990, tem o marco na proposta dos "Novos Modelos de Gestão". Outro projeto é o da reforma sanitária flexibilizada, que adquire contornos no contexto da reconfiguração do Estado brasileiro sob a égide da agenda neoliberal, com a proposição do SUS possível "pautada por arranjos institucionais, mecanismos gerenciais e responsabilização dos profissionais para a adequação da política de saúde às exigências de um rebaixamento da proposta inicial da reforma sanitária". ${ }^{16, \text { p. } 194}$ E, analisando o governo Temer, as autoras falam da proposição, pelo Ministro da Saúde, do Plano de Saúde Acessível, com as seguintes propostas:

a) Plano Simplificado - cobertura para atenção primária, restrita a consultas nas especialidades previstas no Conselho Federal de Medicina 
ISSN 2179-6750

(CFM) e serviços auxiliares de diagnóstico e terapias de baixa e média complexidade; b) Plano Ambulatorial + hospitalar - cobertura de toda atenção primária, atenção especializada, de média e alta complexidade; c) Plano em Regime Misto de Pagamento - oferece serviço por intermédio de contraprestação mensal para cobertura de serviços hospitalares, terapias de alta complexidade e medicina preventiva; e, quando necessário, atendi- mento ambulatorial. ${ }^{16, \text { p. } 196}$

Ainda, o governo Temer efetivou a articulação com o setor empresarial de saúde, representado pelo Instituto de Coalizão Brasil, que elaborou o documento "Coalizão Saúde Brasil: uma agenda para transformar o sistema de saúde", com objetivo de implantar um novo sistema de saúde para o Brasil em que os setores público e privado construam uma rede integrada de cuidados contínuos, com maior participação da iniciativa privada ${ }^{16}$. Em análise do governo Bolsonaro, as autoras atentam para o desejo do ministro da Saúde Luiz Henrique Mandetta de um sistema privado forte, assinalando as reestruturações dentro do Ministério, entre as quais, a da Secretaria de Atenção à Saúde, que passou a priorizar a "especialização e a criação de um Departamento de Certificação e Articulação com Hospitais Filantrópicos e Privados, estabelecendo contratualização com o setor privado". ${ }^{16, ~ p . ~} 204$

Costa e Soares ${ }^{17}$ discutem a defesa do setor de planos de saúde no Poder Legislativo, com variadas proposições legislativas e ações dos parlamentares eleitos, proporcionando o crescimento do setor durante os anos 2000, em decorrência de investimentos dessas empresas nas campanhas eleitorais. Tal defesa repercute em uma "representação privilegiada dos interesses desse mercado da saúde privada, em detrimento da formulação de leis que garantam o direito à saúde pública". ${ }^{17, ~ p . ~}{ }^{56}$ As autoras atentam para o crescimento do debate da regulamentação dos planos privados de saúde alinhado com o debate nacional de maior regulamentação dos mercados em meio ao contexto de reforma do Estado brasileiro no governo de FHC. Afirmam, ainda, que todos os governos, desde Collor de Mello até Dilma Rousseff, estimularam a expansão dos planos privados de assistência à saúde, principalmente a partir de $\mathrm{FHC}$, com a parceria público-privada no âmbito da gestão dos serviços. A contínua expansão do mercado de planos de saúde promove a restrição ou limitação da expansão do SUS.

No governo Temer, logo após aprovação de medidas de ajuste fiscal, o Ministério da Saúde - MS encaminhou à Agência Nacional de Saúde - ANS proposta de planos privados de assistência à saúde com cobertura restrita. As autoras também discutem o investimento do setor de planos de saúde em campanhas eleitorais e sua consequente influência no âmbito do Poder Legislativo com proposições que poderão se tornar Emendas Constitucionais e Leis Federais. 
ISSN 2179-6750

Mendes e Carnut $^{12}$ argumentam que a manutenção do direito à saúde, no capitalismo contemporâneo, perpassa um ambiente de controvérsias e confusões, sendo privilegiada a operação do direito privado à saúde. Neste sentido, nas últimas três décadas, o Estado brasileiro concedeu incentivo à iniciativa privada, enfraquecendo a saúde universal. Uma das estratégias apresentadas pelos autores consiste em "elevadas transferências de recursos ao setor privado via recursos direcionados às modalidades privatizantes de gestão (Organizações Sociais - OSs, Organizações da Sociedade Civil de Interesse Público - Oscips, Empresa Brasileira de Serviços Hospitalares - Ebserh e Fundações Estatais Públicas de Direito Público/Privado com contratos celetistas)". ${ }^{12, \text { p. } 24}$

Sousa $^{22}$ assinala que a lógica liberal tem sido imposta pelos organismos internacionais desde os anos 1990, lógica essa que entende que o acesso deve ser viabilizado por meio do mercado, uma vez que a cobertura da saúde pelo sistema público sobrecarrega o Estado e não comporta a totalidade da população. Dessa forma, a cobertura deve ser focalizada, sendo ofertada para os pobres. Neste contexto, Sousa ${ }^{22}$ afirma que houve um avanço do setor privado, confrontando com a universalização e a privatização com o crescimento do mercado de planos de saúde, impedindo o projeto do SUS. Para a autora, isso pode ser constatado nos resultados da Reforma do Estado, de 1995, traçada por Bresser-Pereira, que ampliou as possibilidades de privatização da saúde, com deslocamento da prestação de bens e serviços públicos para o setor privado por meio de entidades não governamentais, filantrópicas, comunitárias e de empresas privadas. Tal constatação não se reverteu no governo petista, que contribuiu para maior abertura à expansão do setor privado por meio da oferta/venda de serviços ao SUS, ampliando a saúde suplementar e a inserção de novas formas de gestão (terceirizações, fundações e OSs).

Santos $^{23}$ discute sobre os projetos de saúde em disputa, dos quais, o projeto privatista impõe ao Estado apenas a garantia de oferta de ações mínimas de saúde, direcionadas à população que não pode pagar, fortalecendo um sistema para o consumidor, ficando o SUS restrito aos pobres com programas precários e focalizados. Nesse mote, o poder público insere os novos modelos de gestão que entregam as tarefas do setor público ao setor privado.

Davi et al. ${ }^{24}$ mencionam a constatação da tendência de privatização das políticas de saúde nos governos pós-1990, em um cenário de agenda neoliberal determinado pelos organismos internacionais, com consequente fortalecimento da mercantilização da saúde pelo Estado em atendimento ao grande capital.

Nogueira $^{25}$ assinala para o direito à saúde novos encaminhamentos dados pelos organismos internacionais a partir dos anos 2000, em que está sendo cada vez mais tratado como bem privado em detrimento de uma visão de bem público. "Ainda, os imperativos 
ISSN 2179-6750

macroeconômicos e as estratégias mercadológicas utilizadas em larga escala para transformar a saúde em um objeto corriqueiro de consumo vêm contribuindo para a metamorfose na concepção de direito à saúde". ${ }^{25}$ p. 20

Calipo e Soares ${ }^{26}$ comentam acerca da criação das Organizações Sociais que estas trazem para a saúde a lógica de mercado, privatizando os equipamentos de maior complexidade, tornando o setor privado um sistema essencial que constitucionalmente era complementar.

Dal Prá 27 trata da transformação do direito à saúde submetido às relações entre Estado, capital e trabalho, a partir da década de 1980, sendo a saúde inserida no mercado por representar uma nova ocasião de lucratividade. Por meio da prerrogativa de uma imagem de Estado ineficaz e incompetente, a responsabilidade estatal é transferida para os setores da sociedade e do mercado. A autora assinala que o Banco Mundial, um dos grandes articuladores das reformas do setor administrativo da saúde, ditou orientações subordinando os gastos ao sucesso do ajuste estrutural, com limitação da ação do Estado na economia.

$\mathrm{Na}$ análise dos aspetos da privatização da saúde discutidos pelos artigos desta revisão, pode-se inferir que os principais mecanismos são a transferência de responsabilidade do setor público para o setor privado por meio de estímulos aos planos privados de assistência à saúde e implantação de modelos privatizantes de gestão.

Para essa discussão, compreende-se ser importante a contribuição de Rosado e Freitas, ${ }^{36}$ quando ressaltam que a política de saúde brasileira, advinda de uma construção de direito à saúde marcada por disputas de interesses antagônicos de classes em um modelo societário capitalista, possui ênfase na lógica de mercado, uma vez que, na perspectiva do capital, a saúde é um campo de alta lucratividade, dada sua importância para a vida humana.

Ainda, Bravo ${ }^{37}$ acrescenta que há uma consolidação de um projeto de saúde voltado ao mercado, em que a contrarreforma do Estado com direcionamento neoliberal, em favor de um modelo gerencial, dita que o Estado capitalista deve ser o promotor e regulador do desenvolvimento social e econômico, deixando de exercer suas funções diretamente, passando-as ao setor privado.

Nesses termos, repousando as características gerais do neoliberalismo na premissa da soberania do mercado, privatização e terceirização, o Estado capitalista opera garantindo a acumulação de capital. ${ }^{30}$

Com relação à segunda temática, o financiamento, é possível destacar 7 artigos. $^{12,16,18,22,24,28}$ Bravo, Pelaez e Menezes ${ }^{16}$ expõem que, como medida drástica para o financiamento da saúde, no governo Temer, tem-se a aprovação da Emenda Constitucional - EC 95/2016, que congela os gastos públicos por vinte anos, gerando enormes impactos 
na saúde com uma perda de $\mathrm{R} \$ 654$ bilhões de reais nesse período. Outro ataque aos recursos da saúde são os subsídios fiscais da Medida Provisória 839/2018, que se traduzem em desoneração para a Seguridade Social, com impacto direto para o financiamento da política de saúde e prestação de serviços.

Em análise dos primeiros seis meses do governo Bolsonaro, Bravo e Pelaez e Menezes ${ }^{16}$ indicam que houve proposições de medidas que são mecanismos de privilégio ao setor industrial, que objetivou reduzir a tributação de cigarros fabricados no Brasil, mostrando interfaces de interesses econômicos do setor industrial produtor de tabaco em detrimento da saúde pública.

Costa e Soares ${ }^{17}$ afirmam que todos os governos, desde Collor de Mello, estimularam o mercado privado da saúde e, especificamente, os de planos privados de assistência à saúde. Tal estímulo se deu via isenções fiscais e pelo subfinanciamento crônico da política de saúde, principalmente a partir do governo de FHC. Enfatizam que o subfinanciamento da política consiste em estratégia fundamental para a expansão do setor privado, e, mesmo nos governos petistas, esse subfinanciamento persistiu.

Mendes e Carnut ${ }^{12}$ corroboram a questão do subfinanciamento, destacando que este tem sido estrutural durante o período de existência do SUS, indicando, por exemplo, que a saúde nunca recebeu os 30\% dos recursos da Seguridade Social que deveriam ser destinados para seu orçamento, acarretando dificuldades para assegurar a efetivação do direito à saúde. Ainda, a apropriação do fundo público na saúde pelo capital fictício expropria o direito à saúde por via do aumento do gasto com os juros da dívida, que representou 6,6\% do PIB entre 1995 e 2018, enquanto o gasto com a saúde se manteve em $1,7 \%$ no mesmo período. Mencionam, também, a Desvinculação das Receitas da União (DRU) e as renúncias fiscais como mecanismos que prejudicam o financiamento do SUS.

Cislaghi $^{18}$ e Sousa ${ }^{22}$ também assinalam os mecanismos de renúncia fiscal e desonerações dos governos brasileiros que retiram bilhões do setor saúde. Por sua vez, Davi et al. ${ }^{24}$ corroboram a questão do privilégio do pagamento dos juros da dívida, em detrimento dos gastos públicos em setores como a saúde.

Marque e Mendes ${ }^{28}$ assinalam que, no ano de 1993, o embate do SUS por recursos já se inicia com a não transferência ao Ministério da Saúde de 15,5\% da arrecadação da contribuição de empregados e empregadores previstos no orçamento da União. As tentativas de ataques ao orçamento continuaram e nos anos 2000, o governo federal descumpriu o estabelecido na EC 29/2000, considerando como despesas de saúde, itens que não se referem a ações típicas de saúde, acarretando diminuição dos recursos financeiros do SUS. 
Ao refletir sobre essas medidas que vão expropriando os recursos públicos, Mendes ${ }^{38}$ coloca que, nos tempos de dominância do capital financeiro, isto é, desde os anos 1980 até o momento atual, os recursos públicos são disputados pelo sistema financeiro pelo interesse de manter o pagamento dos juros da dívida pública acobertado pela permissão, por parte do Estado, de apropriação do fundo público para esse fim.

Na esteira da socialização dos custos das crises do capitalismo, o fundo público vai sendo apropriado por meio de renúncias fiscais em favor do setor empresarial, acobertado pelo discurso de proteção do emprego, bem como é destinado à compra de ativos podres de empresas em dificuldades, ainda, por meio das parceiras público-privadas, entre outros mecanismos. $^{32}$

A abordagem da terceira temática, os efeitos para a classe trabalhadora, foi encontrada em três artigos. ${ }^{18,20,21}$

Cislaghi $^{18}$ chama atenção para a precarização dos contratos de trabalho dos profissionais de saúde como forma de minar a resistência que estes impõem ao processo de desmonte do SUS.

Para Lourenço, ${ }^{20}$ além da problemática diretamente relacionada ao trabalho e seu ambiente, os efeitos advindos da necessidade de valorização do capital, em particular, por meio da estratégia da terceirização, residem na maior propensão aos acidentes de trabalho. O Brasil se encontra em quarto lugar no ranking mundial desses tipos de acidentes, bem como das patologias vinculadas ao trabalho, como Lesões por Esforços Repetitivos - LER e Doenças Osteomusculares Relacionadas ao Trabalho - DORT e sofrimentos mentais. Lourenço ${ }^{20}$ chama atenção para estratégias de negação dos direitos dos trabalhadores, principalmente quando adoecem, com políticas de saúde e segurança no trabalho repressivas.

Ferreira e Amaral21 apontam para a "falta de respostas dos serviços públicos às necessidades de saúde, especialmente no momento em que se vê comprometida a capacidade produtiva do trabalhador",21, p. 180 também quando há inviabilização de tratamento de saúde em decorrência de falta de estrutura física adequada à demanda. As autoras discorrem acerca da dificuldade e da demora para realização de cirurgias, exames, tratamentos de trabalhadores com agravos à saúde vinculados ao trabalho, tornando difícil a reinserção no mercado de trabalho.

A partir da análise dos aspectos apresentados nessa dimensão, constata-se a expressão da expropriação do direito à saúde na classe trabalhadora, que, apresentando agravos à saúde advindos do próprio sistema de acumulação capitalista, encontra dificuldades no acesso aos serviços de saúde. 
ISSN 2179-6750

Alves e Santos ${ }^{39}$ ratificam que, em decorrência das estratégias de apropriação dos recursos da saúde pelo capital, um dos fatores a serem observados é a capacidade de assistência em saúde oferecida pelo SUS, que tem sofrido diminuição em número de leitos hospitalares e redução da capacidade de atendimento na atenção primária.

\section{Expropriação e capitalismo contemporâneo}

Nesta dimensão, os artigos analisados abordam a crise do capitalismo e a contrarreforma do Estado brasileiro como contexto para expropriação dos meios de condições da vida social para produção e reprodução do capital.

Destarte, 14 artigos $^{12,16-27,29}$ assinalam essas características como ordenadoras das decisões relativas às políticas sociais, inclusive, às de saúde, gerando expropriação de seus direitos.

Bravo, Pelaez e Menezes ${ }^{16}$ mencionam as medidas adotadas com relação à política de saúde desde a década de 1990 como formas de apropriação do fundo público para a garantia de acumulação de capital, com disputas entre os projetos para a saúde em uma conjuntura de desenvolvimento do capitalismo em sua fase neoliberal.

Costa e Soares ${ }^{17}$ afirmam que a contrarreforma dos anos 1990 intensificou a disponibilidade do aparato do Estado em favor da valorização dos mercados de planos privados de assistência à saúde. Assinalam para a ampliação das necessidades do capital sobre o fundo público em virtude das buscas da burguesia pelo aumento da taxa de lucro em meio à crise econômica, que se expressou de forma mais grave a partir de 2015 .

Mendes e Carnut ${ }^{12}$ discutem a expropriação do direito à saúde como parte integrante da crise do capitalismo e da atuação do Estado capitalista. Nesse contexto, os autores ressaltam que esse Estado, ao enfrentar a crise, reforça a valorização financeira, assegurando a apropriação do fundo público por meio do capital fictício.

Cislaghi $^{18}$ argumenta na mesma direção, assinalando que, em resposta à crise do capitalismo, o Estado e as políticas sociais são cada vez mais colocados a serviço do capital no neoliberalismo.

Alencar Junior e Salvador ${ }^{19}$ mencionam que a crise do capital e a contrarreforma do Estado dificultaram a efetivação dos direitos sociais, estando o fundo público presente na reprodução do capital e da força de trabalho, assumindo cada vez mais importância no capitalismo contemporâneo como fonte para realizar investimentos, viabilizando a reprodução da força de trabalho e transferindo recursos para o capital financeiro por intermédio da dívida pública. 
ISSN 2179-6750

Lourenço $^{20}$ ressalta que as medidas neoliberais contra os trabalhadores são estratégias de enfrentamento à crise do capital, taxando os direitos do trabalho como riscos empresariais.

Ferreira e Amaral $^{21}$ mencionam que a crise do capitalismo atinge o âmbito da produção e reprodução social, acarretando precarização e retração dos direitos conquistados pelos trabalhadores. Sousa ${ }^{22}$ afirma que o ônus das crises capitalistas sempre recai sobre os direitos sociais, sendo a reestruturação produtiva e os ajustes neoliberais as principais medidas adotadas, com o capital financeiro assumindo destaque no processo de acumulação.

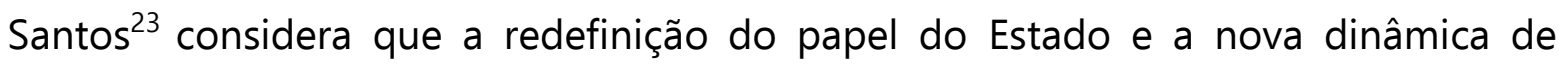
acumulação do capital provocam a precarização das políticas sociais, com ataques ao direito à saúde.

Davi et al..$^{24}$ afirmam que os efeitos das crises do capital prejudicam os direitos sociais em que a ideologia neoliberal indica as diretrizes para a superação da crise. A contrarreforma do Estado capitalista e a reorganização da produção conduzem as políticas sociais em direção à negação dos direitos conquistados.

Para Nogueira, ${ }^{25}$ a discussão sobre o direito à saúde torna quase obrigatória a correlação com as alterações recentes por meio do fundo público apropriado para a reprodução do capital.

Calipo e Soares ${ }^{26}$ discutem a relação da Reforma do Estado brasileiro com a perda do direito universal à saúde. Concluem que, no Estado liberal, a política torna-se função da economia, passando a reger as relações políticas. Dal Prá ${ }^{27}$ discorre acerca do direito à saúde no contexto de Reforma do Estado brasileiro, em que este deixa de ser garantidor de direitos e passa a priorizar a reprodução do capital. Simionatto e Nogueira, ${ }^{29}$ ao se referirem aos impactos da reforma do Estado sobre o direito à saúde, articulam-nos com a alteração do padrão de acumulação do capital.

A incursão dos aspectos identificados nesta dimensão de análise permite inferir que, para os autores, os direitos sociais, inclusive o da saúde, inscritos na Constituição de 1988, tiveram sua implementação influenciada pela contrarreforma do Estado brasileiro realizada nos anos 1990, sob a lógica neoliberal. A contribuição de Ianni ${ }^{40}$ para essa reflexão é incontornável. Para ele, o neoliberalismo objetiva o Estado "mínimo", com desregulamentação de atividades econômicas, privatizações de empresas, instituições e organizações estatais, sendo liberado do poder estatal qualquer empreendimento econômico e social que interesse ao capital.

Por sua vez, no contexto da crise do capitalismo, é imperativo o papel do fundo público para amparar o capital, e, nessa perspectiva, Behring ${ }^{32}$ afirma que: 
o fundo público participa do processo de rotação do capital, tendo em perspectiva o processo de reprodução capitalista, como um todo, especialmente em contextos de crise. Por outro lado, o fundo público realiza mediações na própria repartição da mais-valia - pelo que é disputado politicamente pelas várias facções burguesas, cada vez mais dependentes desta forma de retorno mediado por um Estado, por sua vez, embebido do papel central de assegurar as condições gerais de produção. ${ }^{32, \text { p. } 21}$

Já a respeito da destruição de direitos e políticas sociais e do uso do fundo público, Boschetti ${ }^{7}$ acrescenta a seguinte ideia:

Sua corrosão objetiva reduzir a parcela do fundo público utilizada em sua realização e transferi-la para o capital por meio do pagamento dos juros e amortizações da dívida pública, mercantilizar bens e serviços públicos para ampliar novos nichos de acumulação, e reduzir diversas formas de proteção para disponibilizar a força de trabalho para o capital. ${ }^{7,}$ p. 4

Nesses termos, com base na contribuição de Fontes, ${ }^{4}$ pode-se assinalar que a expropriação secundária tem ocorrido com a retirada de direitos por meio da precarização das políticas sociais e de saúde, a partir de mecanismos de subfinanciamento e privatizações.

\section{Considerações finais}

Os processos de expropriação têm permeado as relações sociais na sociedade capitalista. No capitalismo contemporâneo, essa expropriação tem se expressado na retirada de direitos conquistados pela classe trabalhadora.

A partir dos resultados encontrados nesta revisão, pode-se concluir que os mecanismos de expropriação utilizados pelo capital, no capitalismo contemporâneo, têm na intervenção do Estado seu garantidor por via do fundo público como protetor do sistema financeiro, usurpando recursos orçamentários das políticas públicas ou por via da privatização com estímulo ao mercado livre da saúde e entrega da gestão dos serviços públicos de saúde ao setor privado.

Esse processo de expropriação ganhou intensidade na saúde a partir de 1990, ao longo dos governos, contribuindo para a focalização e a precarização da assistência ofertada pelo SUS, colocando em xeque a garantia do direito à saúde para a classe trabalhadora.

\section{Contribuição autoral}

A autora APCC participou da concepção, planejamento, análise, interpretação e redação do trabalho; e, o autor AM participou na interpretação e redação do trabalho. Ambos/todos os autores aprovaram a versão final encaminhada. 


\section{Referências}

1. Lupatini M. Notas sobre a expropriação na "odisseia" do capital. In: Boschetti I. Expropriação e direitos no capitalismo. São Paulo: Cortez; 2018. p. 63-99.

2. Boschetti I. Expropriação e direitos no capitalismo. São Paulo: Cortez; 2018. Expropriação de direitos e reprodução da força de trabalho; p. 131-65.

3. Marx K. O capital: crítica da economia política. São Paulo: Boitempo Editorial; 2013.Assim chamada acumulação primitiva; Livro I.

4. Fontes V. A transformação dos meios de existência em capital: expropriações, mercado e propriedade. In: Boschetti I. Expropriação e direitos no capitalismo. São Paulo: Cortez; 2018. p. 17-61.

5. Mendes Á, Carnut L. Crise do capital, estado e neofascismo: Bolsonaro, saúde pública e atenção primária. Rev Soc Bras EconPolit. 2020;(57):174-210.

6. Fine B, Saad-Filho A. Thirteen things you need to know about neoliberalism. Crit Sociol.2017;43(4-5):685-706. https://doi.org/10.1177/0896920516655387.

7. Boschetti I. Supressão de direitos no capitalismo: uma forma contemporânea de expropriação?. In: Anais do colóquio internacional Marx e o marxismo 2017: de O capital à revolução de outubro (1867-1917). Niterói: NIEP-Marx; 2017.

8. Mota AE. Sobre as expropriações contemporâneas: hipóteses e reflexões. Anais do colóquio internacional Marx e o marxismo 2017: de O capital à revolução de outubro (1867-1917). Niterói: NIEP-Marx; 2017.

9. Mascaro AL. Crise e golpe. São Paulo: Boitempo; 2018.

10. Demier F. Da ditadura bonapartista à democracia blindada. In: Mattos MB, organizador. Estado e formas de dominação no Brasil contemporâneo. Rio de Janeiro: Consequência Editoras; 2017. Capítulo 3; p. 67-101.

11. Mendes Á. Tempos turbulentos na saúde pública brasileira: impasses do financiamento no capitalismo financeirizado. São Paulo: Hucitec; 2012.

12. Mendes Á, Carnut L. Capital, estado, crise e a saúde pública brasileira: golpe e desfinanciamento. SER Soc. 2020;22(46):9-32. https://doi.org/10.26512/ser_social.v22i46.25260.

13. Netto JP. Introdução ao estudo do método de Marx. São Paulo: Expressão Popular; 2011. 
ISSN 2179-6750

14. Müller ML. Exposição e método dialético em "O capital". Bol Seaf Belo Horizonte.1982;2:17-41.

15. Soares CB, Campos CMS, Yonekura T. Marxismo como referencial teórico-metodológico em saúde coletiva: implicações para a revisão sistemática e síntese de evidências. Rev Esc Enferm USP. 2013;47(6):1403-9. https://doi.org/10.1590/S0080-623420130000600022.

16. Bravo MIS, Pelaez EJ, Menezes JSB. A saúde nos governos Temer e Bolsonaro: lutas e resistências. SER Soc. 2020;22(46):191-209.

https://doi.org/10.26512/ser_social.v22i46.25630.

17. Costa LTC, Soares RC. Planos de Saúde, interesses no Poder Legislativo e ameaças ao direito público. SER Soc. 2020;22(46):54-71. https://doi.org/10.26512/ser_social.v22i46.25486.

18. Cislaghi JF. Privatização da saúde no Brasil: da ditadura do grande capital aos governos do PT. Em Pauta. 2019;(43):60-73. https://doi.org/10.12957/rep.2019.42502.

19. Alencar Junior OG, Salvador ES. Finanças, fundo público e financiamento da Seguridade Social no Brasil. Rev Katálysis. 2015;18(2):239-48. https://doi.org/10.1590/141449802015180200010.

20. Lourenço EÂS. Terceirização: a derruição de direitos e a destruição da saúde dos trabalhadores. Serv Soc Soc. 2015;(123):447-75. https://doi.org/10.1590/0101-6628.032.

21. Ferreira AMA, Amaral AS. A saúde do trabalhador e a (des)proteção social no capitalismo contemporâneo. Rev Katálysis. 2014;17(2):176-84. https://doi.org/10.1590/S141449802014000200003.

22. Sousa AMC. Universalidade da saúde no Brasil e as contradições da sua negação como direito de todos. Rev Katálysis. 2014;17(2):227-34. https://doi.org/10.1590/S141449802014000200008.

23. Santos MA. Lutas sociais pela saúde pública no Brasil frente aos desafios contemporâneos. Rev Katálysis. 2013;16(2):233-40. https://doi.org/10.1590/S141449802013000200009.

24. Davi J, Serpa MA, Silva SSS, Medeiros Junior G, Santos MAN. A seguridade social em tempos de crise do capital: o desmonte de seu orçamento. SER Soc. 2010;12(26):59-87. https://doi.org/10.26512/ser_social.v12i26.12707. 
25. Nogueira VMR. Direito à saúde na sociedade contemporânea: um convite à reflexão. SER Soc. 2009;(10):9-32. https://doi.org/10.26512/ser_social.v0i10.12919.

26. Calipo $S M$, Soares $C B$. Público e privado na política de assistência à saúde no Brasil. Soc Debate. 2008;14(1):119-38.

27. Dal Prá KR. Reforma do estado: a saúde subordinada as contratualidades do mercado?. Soc Debate. 2008;14(1):139-53.

28. Marques RM, Mendes Á. Servindo a dois senhores: as políticas sociais no governo Lula. Rev Katálysis. 2007;10(1):15-23. https://doi.org/10.1590/S1414-49802007000100003.

29. Simionatto I, Nogueira VMR. Mercosul e reforma do estado: impactos sobre o direito à saúde. Rev Katálysis.1998;(3):11-8.

30. Mendes Á, Alcantara AC, Alcantara Filho JL. Sistema único de saúde: entre a universalidade e a privatização. In: Silva AA, Paz RDO, editores. Políticas públicas e direitos sociais no contexto da crise capitalista contemporânea. São Paulo: Paulinas; 2019. p. 66-84.

31. Ferreira MRJ, Mendes Á. Mercantilização nas reformas dos sistemas de saúde alemão, francês e britânico. Cienc Saude Colet. 2018;23(7):2159-70. https://doi.org/10.1590/141381232018237.12972018.

32. Behring ER. Crise do capital, fundo público e valor. In: Boschetti I, Behring ER, Santos SMM, Mioto RCT, organizadoras. Capitalismo em crise, política social e direitos. São Paulo: Cortez; 2010. p. 13-34.

33. Mendes Á. O fundo público e os impasses do financiamento da saúde universal brasileira. Saude Soc. 2014;23(4):1183-97. https://doi.org/10.1590/S010412902014000400006.

34. Behring ER. Rotação do capital e crise: fundamentos para compreender o fundo público e a política social. In: Salvador E, Boschetti i, Granemann S, organizadores. Financeirização, fundo público e política social. São Paulo: Cortez; 2012. p. 153-80.

35. Marx K. O capital: crítica da economia política. São Paulo: Boitempo; 2017. Livro III.

36. Rosado IVM, Freitas GA. As contradições do direito à saúde no capitalismo: apontamentos da realidade brasileira. SER Soc. 2020;22(47):368-88. https://doi.org/10.26512/sersocial.v22i47.25428. 
37. Bravo MIS. Política de saúde no Brasil. In: Mota AE, Gomes L, Bravo MIS, Teixeira M, Marsiglia R, Uchôa R, et al., organizadores. Serviço social e saúde: formação e trabalho profissional. São Paulo: Cortez, 2006. p. 1-24.

38. Mendes Á. O subfinanciamento e a mercantilização do SUS no contexto do capitalismo contemporâneo em crise. In: Bravo MIS, Andreazzi MFS, Menezes JSB, Lima JB, Souza RO, organizadoras. A mercantilização da saúde em debate: as organizações sociais no Rio de Janeiro. Rio de Janeiro: Rede Sirius; 2015. p. 12-9.

39. Alves PKL, Santos VM. Expropriações contemporâneas: o apoio estatal à saúde suplementar no Brasil. Argumentum.2020;12(2):253-69. https://doi.org/10.18315/argumentum.v12i2.29214.

40. Ianni O. Globalização e neoliberalismo. Sao Paulo Perspect. 1998;12(2):27-32.

\section{Minicurrículo}

Alexsandra Pinheiro Cavalcante Costa | https://orcid.org/0000-0003-3161-3208 http://lattes.cnpq.br/ 8276918353584207

Áquilas Mendes | https://orcid.org/0000-0002-5632-4333 http://lattes.cnpq.br/7310723011915165 